Stručni rad

DOI: $10.17234 /$ Croatica.42.2

UDK: 81 '362

811.163.42’282Pranjković, I.

Primljen: 4. XII. 2017.

Prihvaćen: 26. I. 2018.

\title{
KONTRASTIVNA SINTAKSA \\ HRVATSKOGA JEZIKA U GIMNAZIJSKOM \\ UDŽBENIKU IVE PRANJKOVIĆA \\ S MOTRIŠTA KONTRASTIVNOG PRISTUPA NARJEČNIM TEMAMA
}

\author{
Jadranka Nemeth-Jajić \\ Filozofski fakultet Sveučilišta u Splitu \\ Odsjek za hrvatski jezik i književnost \\ jadranka@ffst.hr
}

U gimnazijskom udžbeniku Hrvatski jezik 3 Ive Pranjkovića prvi je put u sintaktičkom opisu hrvatskih narječja primijenjen kontrastivni pristup i time uspostavljen nov model predstavljanja narječnih tema u srednjoškolskim udžbenicima. Riječ je o udžbeničkoj cjelini u kojoj se usporedno donose sintaktičke osobitosti čakavskoga, kajkavskoga i štokavskoga narječja u njihovu međusobnom odnosu i u odnosu prema standardnome jeziku. Kontrastivni pristup u učenju i poučavanju hrvatskoga jezika nije nov, no ipak se u praksi nedostatno primjenjuje, pa navedena udžbenička cjelina tim više zavrjeđuje pozornost. Stoga se u ovome radu utvrđuje način na koji se kontrastivni pristup očituje $u$ tom gimnazijskom udžbeniku i uspoređuje se s pristupima narječnim temama u drugim srednjoškolskim udžbenicima. Ujedno se upućuje na mogućnosti primjene kontrastivnog pristupa i razloge zbog kojih je taj pristup poželjan u nastavi hrvatskoga jezika na svim naobrazbenim stupnjevima.

Ključne riječi: hrvatska narječja, kontrastivni pristup, srednjoškolski udžbenici hrvatskoga jezika 


\section{UVOD}

Ivo Pranjković, dugogodišnji sveučilišni profesor, istaknut hrvatski jezikoslovac, kroatist i gramatičar posebno zaslužan za sintaktički opis suvremenoga hrvatskoga jezika, autor je dvaju jezičnih udžbenika za treći razred gimnazije. U skladu s glavninom profesorova znanstvenoistraživačkoga rada oba udžbenika obrađuju sintaktičku razinu. Prvi, Sintaksa hrvatskoga jezika, objavljen je 1995, drugi, Hrvatski jezik 3, 1998. Upravo potonji privlači našu pozornost zbog toga što se uz sintaktički opis hrvatskoga standardnoga jezika u njemu donosi i udžbenička cjelina u kojoj su izložene sintaktičke osobitosti hrvatskih narječja. Riječ je o tematskoj cjelini u kojoj se nudi "pojednostavljen oblik svojevrsne kontrastivne sintakse štokavskoga, kajkavskoga i čakavskoga narječja" (Pranjković 2004: 117-118), dakle riječ je o cjelini u kojoj je pri jezičnom opisu primijenjen kontrastivni pristup.

Kontrastivni pristup, koji podrazumijeva iskorištavanje učenikova dijalektnoga, zavičajnog idioma u procesu usvajanja standardnojezičnoga idioma, u učenju i poučavanju hrvatskoga jezika nije nov. Uobičajeno se vezuje uz načelo zavičajnosti kojem se u metodičkoj teoriji i praksi, osobito od osamdesetih godina prošloga stoljeća, pridaje značajna pozornost u svim nastavnim područjima hrvatskoga jezika i izvannastavnim djelatnostima jezično-umjetničkoga područja (Visinko 2010: 115), a u jezičnoj je nastavi "dopuna načelu književnog jezika i polazi od zahtjeva da se u nastavi književnog jezika iskoristi učenička imanentna gramatika, što najčešće znači - gramatički sustav zavičajnog narječja koji se više ili manje ne podudara sa sustavom književnoga jezika" (Težak 1996: 97). U novije vrijeme kontrastivni pristup uporište nalazi i u teoriji okomite dvojezičnosti koja se "očituje kao odnos različitih dijalektalnih idioma i standardnoga jezika unutar istoga materinskoga jezika" (Pavličević-Franić 2005: 63-64), u kroatističkim pogledima na hrvatski jezik, koji bitno određuje tronarječna uzajamnost (usp. Zapisnici Vijeća za normu hrvatskoga standardnoga jezika 2013: 67), a uklapa se i u koncept hrvatskoga standardnoga jezika prihvaćen 2007. u Razredu za filologiju Hrvatske akademije znanosti i umjetnosti:

[...] hrvatski standardni jezik nema dijalekatske osnovice, niti je istovjetan s nekim dijalektom posebno, on je samo dosljedna stilizacija novoštokavske jekavštine zapadnoga tipa, uz tronarječnu nadogradnju prema višestoljetnoj hrvatskoj književnoj baštini; [...] općehrvatski standardni jezik je suodnos sva tri narječja i mogućnost komunikacije među njima, što ga čini specifičnim i jedinstvenim te neovisnim o svim drugim srodnim ili manje srodnim jezicima (v. Lukežić 2010: 15). 
Promatra li se u okomici odgojno-obrazovnoga sustava i s obzirom na dob učenika, kontrastivni je pristup primjenjiv na svim naobrazbenim stupnjevima, no ipak je u literaturi pomnije razrađen za osnovnoškolsku negoli srednjoškolsku nastavu. Pritom ponajprije mislimo na metodu kontrastivne analize i na izradu školske razlikovne gramatike i školskoga razlikovnog rječnika, koji su i zasnovani na kontrastivnom pristupu, pri čem na njihove dobrobiti za jezičnu izobrazbu učenika podsjeća Težak (1996: 410, 417-418). ${ }^{1}$ U nastavnoj praksi, u redovitoj nastavi hrvatskoga jezika, kontrastivni se pristup općenito nedostatno primjenjuje, a jedan od razloga zašto je tomu tako jest i nedostatak udžbenika temeljenih na tom pristupu (usp. Nemeth-Jajić i Turza-Bogdan 2014: 184). ${ }^{2}$ Primjena toga pristupa u ranoj školskoj dobi poželjna je pak ponajprije zbog didaktičkih razloga, jer oslanjanje na učeničku imanentnu gramatiku pospješuje postupno usvajanje standardnoga jezika (usp. Peruško 1961: 8; Težak 1980: 42-43, 1996: 97-98, 406-412; Gudelj-Velaga 1990: 84-96; Visinko 2010: 114-127; Turza-Bogdan 2013 i dr.), te ujedno pridonosi razvijanju pozitivnih stavova prema svojem i drugim dijalektima, očuvanju i njegovanju jezične i kulturne baštine. U višim razredima osnovne škole, kad učenici već steknu temeljna jezična znanja, poželjno je upućivati ih u prikupljanje građe za školsku razlikovnu gramatiku i izradu razlikovne gramatike, ${ }^{3}$ jer će učenici na taj način spoznavati i standardnojezične i dijalektne jezične pojave: "Poznavati dijalekt, odnosno svoj zavičajni idiom, znači poznavati njegovu morfologiju i sintaksu, kao i ostale jezične razine, i znati njegovo mjesto u društvenoj zajednici, osvijestiti razloge uporabe zavičajnoga idioma te njegov (su)odnos sa standardnim jezikom" (Visinko 2010: 116). U nastavnome programu međutim zavičajni govor i narječje kao nastavne teme izrijekom se navode tek u četvrtome razredu, a zastupljeni su još u petom i osmom razredu. Obrazovna postignuća koja se uz njih vezuju u četvrtom su razredu "razlikovati književni jezik od zavičajnoga govora;

1 Težak navodi i primjere školskih razlikovnih gramatika iz svih triju hrvatskih narječja (1996: 424-446).

2 U pogledu priručničke literature ipak se zapažaju pomaci, pa svraćamo pozornost na mali hrvatski zavičajni rječnik Zaviri (ur. Jelaska i Kovačević 2003) i na natječaj Slovarica mojega kraja, koji su pokrenuli Školska knjiga i Osnovna škola Augusta Šenoe u Zagrebu, a na koji je pristiglo dvjestotinjak radova iz svih hrvatskih krajeva - slovarica što su ih učitelji razredne nastave izrađivali sa svojim učenicima. Rezultati natječaja objavljeni su u travnju 2017.

3 Rad na školskoj razlikovnoj gramatici neorićkoga štokavskog govora u splitskom zaleđu, koji je provodila sa svojim učenicima, opisala je Bampa-Listeš (2003: 339). Posrijedi je projektna nastava hrvatskoga jezika, pa su učenici oni koji istražuju, intervjuiraju sumještane, prikupljaju građu, zapažaju i bilježe, a značajke takva rada nose obilježja terenskoga istraživanja dijalektologa. U tom smislu postojeće razlikovne gramatike mogu biti oslonac pri radu, no držimo da za učenike veću vrijednost ima ako oni poduzimaju takva istraživanja. 
odrediti svoj zavičajni govor u odnosu na jedno od tri narječja hrvatskoga jezika; usmeno i pisano komunicirati na svome zavičajnome govoru" (Nastavni plan i program za osnovnu školu 2006: 33), u petome "razlikovati zavičajne idiome i književni jezik; osvijestiti postojanje različitih narodnih govora i potrebu njihova njegovanja" (isto: 35), a u osmome razredu to su "razlikovati zavičajni govor i narječje od književnoga jezika; razumjeti odnos i ulogu zavičajnoga govora i narječja prema hrvatskome književnome jeziku; zamjenjivati riječi, izraze i rečenice zavičajnoga govora hrvatskim književnim jezikom i obratno" (isto: 47).

U srednjoškolskim nastavnim programima narječne su teme predložene u skladu s načelom sustavnosti poučavanja jezičnih razina s jezikoslovnog stajališta, s jedne strane, i kontrastivnog pristupa, s druge strane, pa se u prvome razredu proučavaju glavne osobitosti fonemskog i naglasnog sustava čakavskog i kajkavskog narječja u usporedbi s hrvatskim standardnim jezikom (Nastavni programi za gimnazije i strukovne škole 1995: 152), u drugome razredu glavne značajke oblikotvornog ustrojstva čakavskog i kajkavskog narječja u usporedbi s hrvatskim standardnim jezikom (padežni sustav, sustav glagolskih oblika i drugih oblika promjenljivih riječi) (isto: 154), a u trećem razredu osnovne sintaktičke osobitosti čakavskog i kajkavskog narječja prema hrvatskome standardnom jeziku (isto: 156). U četvrtome razredu, kad se sustavno obrađuje leksikologija, dijalektni se leksik promatra s motrišta standardnoga jezika u sklopu teme Područna raslojenost leksika (lokalizmi, regionalizmi i dijalektizmi; vrste dijalektizama; stilska obilježenost dijalektizama) (usp. isto: 158). U skladu s nastavnim programom navedene su narječne teme zastupljene u srednjoškolskim udžbenicima hrvatskoga jezika, no ipak se pri njihovoj razradbi kontrastivni pristup prvi put primjenjuje u udžbeniku Ive Pranjkovića Hrvatski jezik 3, u udžbeničkoj cjelini naslovljenoj Neke sintaktičke osobitosti hrvatskih narječja, koja tim više zavrjeđuje pozornost, pa ćemo ju podrobnije prikazati.

\section{UDŽBENIČKA CJELINA "NEKE SINTAKTIČKE OSOBITOSTI HRVATSKIH NARJEČJA"}

Opsegom to je nevelika udžbenička cjelina, obuhvaća osam od 111 stranica udžbenika, trinaesta je od ukupno njih petnaest na koliko ih je razložen gimnazijski udžbenik Hrvatski jezik $3 .{ }^{4} \mathrm{U}$ njoj su promotrene sintaktičke

4 Udžbenik Hrvatski jezik 3: udžbenik za treći razred gimnazije, imao je šest neizmijenjenih izdanja: ${ }^{2} 2000,{ }^{3} 2001,{ }^{4} 2003,{ }^{5} 2008,{ }^{6} 2009$. 
osobitosti hrvatskih narječja "s obzirom na njihove međusobne sličnosti i razlike" te s obzirom "na sintaktičke osobitosti hrvatskoga standardnog jezika” (Pranjković 1998: 86), pa se kontrastivni pristup očituje dvojako, u odnosu na sličnosti i razlike između čakavskoga, kajkavskoga i štokavskoga narječja i u njihovu odnosu prema hrvatskome standardnome jeziku. U skladu s takvim pristupom izdvojene su i jezične jedinice na sintaktičkoj razini te je pozornost posvećena uporabi vrsta riječi, i to određenim i neodređenim pridjevima, pokaznim i ličnim zamjenicama, brojevima i brojevnim (brojnim) imenicama, ${ }^{5}$ glagolima, prilozima za isticanje, veznicima ali i ako te niječnoj čestici niti, potom uporabi padeža, uporabi glagolskih oblika i redu riječi. Sve promotrene sintaktičke osobitosti oprimjerene su rečenicama.

Iz udžbeničkog prikaza sintaktičkih osobitosti razvidno je da se sličnosti najviše javljaju između kajkavskoga i čakavskoga narječja te između štokavskoga narječja i standardnoga jezika, a u manjoj mjeri između štokavskoga i čakavskoga te štokavskoga i kajkavskoga narječja. Pri upozoravanju na razlike između hrvatskih narječja i standardnoga jezika uzgredno su navedene normativne napomene, a upozoreno je i na sintaktičke osobitosti svojstvene samo pojedinim narječjima. Potkrijepimo to u udžbeničkom prikazu istaknutim sintaktičkim osobitostima.

Sličnosti između kajkavskoga i čakavskoga narječja očituju se u sljedećem: gubljenju sklonidbe neodređenih pridjeva "čak i onda kad je pridjev u ulozi predikatnoga imena" (Pranjković 1998: 86); u češćoj uporabi lične zamjenice on, ona, ono umjesto pokazne zamjenice onaj, ona, ono (čak.: Obećal je dati on ki govori; kajk.: Zeli njega vrazi ki dva drage mrazi.) (isto: 86); u uporabi oblika muškoga roda brojeva $d v a$, oba ili brojne imenice dvojica, trojica kad se označuju osobe različita roda; u uporabi glagolskog oblika vidi (mi) se u značenju činiti se (čini se); u uporabi priloga veliko i kruto kao priloga za isticanje u značenju vrlo, veoma, jako (isto: 87); u čestoj uporabi veznika ali i ako u upitnom značenju; u uporabi negiranog glagola iza negacije niti (čak.: Nit ne kopa nit ne dela; kajk.: Kaj nigdar ne bilo nit ne bu) (isto: 88); u uporabi nenaglašenog dativa posvojno-povratne zamjenice si (prema sebi) (čak.: Bila sam si bila miloga zibrala; kajk.: Rekla mu je da si naj to pela dimo.) (isto: 90); u uporabi akuzativa za živo koji

\footnotetext{
Naziv brojne imenice rabi se u ovome udžbeniku i u gramatici Barić i sur. (1995: 221), a brojevne imenice u Silić-Pranjkovićevoj (2005: 116) i Težak-Babićevoj (1992: 116; 2004: 136) gramatici. U uporabi su oba naziva, no čini se da inačica brojevne potiskuje inačicu brojne imenice.
} 
je jednak genitivu "i onda kad nije riječ o imenicama ili zamjenicama koje znače što živo" (isto: 90); u mogućnosti uporabe akuzativa bez prijedloga umjesto akuzativa s prijedlogom $u$ (čak.: Petnaest dan gre školu $i$ već zna više od meštra; kajk.: Ne mrem se stati gore ja, vile me srce bodejo.) (isto: 90); u mogućnosti uporabe lokativa bez prijedloga (čak.: Nećěs vijeku lika iznać; kajk.: Mladenec ves strahu izišel je iz hiže.) (isto: 90); u čestoj uporabi prezenta svršenih glagola za izricanje buduće radnje (čak.: Ako car zemlje budeš, ko dobro mani učiniš; kajk.: Idem k mojim šogorom, oni mi poveju) (isto: 91); u uporabi futura umjesto prezenta u zavisnim surečenicama namjernih i posljedičnih rečenica koji se tvori od svršenog prezenta glagola biti i glagolskog pridjeva radnog ili od svršenog prezenta glagola biti i infinitiva (čak.: Do grada ću iti da me on vlastelin bude naučiti istinu od toga; kajk.: Drugoga si je izebral da mu bude lovil ribe) (isto: 91); u čestoj uporabi participskih konstrukcija, osobito participa prezenta, i u priložnom i u pridjevskom značenju (čak.: Otkriti rane ti boleće volih neg dopriti do smrti gledeće; kajk.: Premisli mladost cvetuču $i$ mene sestru plačuču) (isto: 92); u mogućnosti da se zanaglasnice ponašaju i kao naglasnice (- Ćě́ iti? - Ću. I - Ste bili tam? - Smu. Bili smu.) (isto: 93).

Navedene sličnosti između čakavskoga i kajkavskoga narječja ujedno su i razlike prema štokavskome narječju (i standardnome jeziku), na što se također upozorava. Pri razmatranju priloga za isticanje svraća se pozornost i na jednu razliku između štokavskoga narječja i standardnoga jezika: "[...] prilog čudo izrazito je obilježen kao pokrajinski (tj. kao svojstvo štokavskoga narječja, ali ne i standardnoga jezika)" (isto: 88). Štokavskom i čakavskom narječju zajednička je pak uporaba pjesničkog vokativa u narodnome pjesništvu, koji dolazi umjesto nominativa, dok je štokavskom i kajkavskom narječju zajedničko to što se posvojni genitiv češće zamjenjuje posvojnim pridjevom (isto: 89) i što im, za razliku od čakavskoga narječja, nije svojstven subjektni instrumental, ${ }^{6} \mathrm{za}$ koji se također navodi da je u standardnome jeziku posve rijedak i obilježen (isto: 91 ). Glede reda zanaglasnica istaknuto je kako glagolske zanaglasnice prethode zamjeničkima u kajkavskom i štokavskom narječju te standardnomu jeziku s izuzetkom zanaglasnice je (treće lice jednine nenaglašenog prezenta glagola biti), koja u štokavskome narječju i standardnome jeziku uvijek dolazi na kraj, iza svih ostalih zanaglasnica, a u kajkavskome narječju i u takvim slučajevima dolazi prije zamjeničkih zanaglasnica (isto: 93).

6 U udžbeniku se rabi naziv instrumental osobe (v. Pranjković 1998: 91). 
Od čakavskih osobitosti navedena je česta uporaba glagolskog oblika mni (mi) se i posuđenice iz talijanskoga para u značenju činiti se (čini se), uporaba priloga golemo kao priloga za isticanje (isto: 87) te osobitosti u uporabi padeža uz koje se napominje kako su svojstvene posebice starim tekstovima: česta uporaba posvojnog genitiva umjesto posvojnog pridjeva, genitiva bez prijedloga uz komparativ ili superlativ, genitiva s prijedlogom od tamo gdje u drugim dvama narječjima "dolazi genitiv bez prijedloga ili genitiv s nekim drugim prijedlozima" (isto: 89) i uporaba instrumentala "koji (posebno u pasivnim konstrukcijama) označuje vršitelja radnje" (isto: 91). Također se upućuje na čakavskome narječju svojstvenu konstrukciju akuzativa s infinitivom i na poredak zamjeničkih zanaglasnica koje u automatiziranom redu riječi dolaze prije glagolskih, a uz obje se jezične pojave napominje da su osobito svojstvene staroj čakavštini (isto: 92).

Od kajkavskih osobitosti navedena je česta uporaba glagolskog oblika zdi se u značenju činiti se (čini se), uporaba priloga čisto kao priloga za isticanje (isto: 87) i pojava osobitog tipa "niječnih rečenica sa složenim glagolskim oblicima, posebice s perfektom, u kojima nisu zanijekani pomoćni glagoli”, svojstvena nekim kajkavskim govorima (isto: 88). Kajkavskom je narječju svojstveno i gubljenje posebnih oblika za vokativ, koji je jednak nominativu, ali se napominje da je to novija pojava i u štokavskom i čakavskom narječju (isto: 89 ).

Dvije su normativne napomene: da se određeni oblici pridjeva u službi predikata u standardnome jeziku smatraju nepravilnima ("Dakle samo: $O n$ je lijep $i$ bogat, a nikako: *On je lijepi $i$ bogati!") (isto: 86); da se uporaba povratno-posvojne zamjenice $s i$ "ne smatra pravilnom u primjerima tipa *Oni su si sjeli ili Oni su si pomislili" (isto: 90).

Kontrastivna sintaksa hrvatskoga jezika - hrvatskih narječja i hrvatskoga standardnoga jezika, doista je, kako je to autor udžbenika istaknuo, pojednostavnjena, a što i priliči udžbeničkoj namjeni. ${ }^{7} \mathrm{U}$ prvome su planu narječja, njihove sličnosti i razlike s obzirom na sustavno izdvojene bitne sintaktičke osobitosti. Kako je riječ o prvom takvu udžbeničkom prikazu, trebalo se odrediti i prema nekim načelnim pitanjima: hoće li se sintaktička obilježja promatrati u sinkroniji ili dijakroniji, kako će se ona oprimjeriti, hoće li se i kako uspoređivati sa standardnojezičnim normama. Potonje osobito privlači pozornost s obzirom na prihvaćeno stajalište po kojem dijalektolozi "ni u kojem slučaju ne bi smjeli dopustiti da u dijalektologiju

Valja ipak primijetiti da je popis i opis sintaktičkih obilježja hrvatskih narječja u ovome udžbeniku iscrpniji od onoga danog u drugim srednjoškolskim udžbenicima. 
uđe norma prema kojoj bi se odstupanja utvrđivala, primjećivala ili sankcionirala" (Bašić i Malnar Jurišić 2016: 71). Pri opisu sintaktičkih obilježja u ovoj su udžbeničkoj cjelini česte napomene o njihovoj svojstvenosti starim, osobito starim čakavskim tekstovima, primjeri su birani pretežito iz tekstova starije i usmene hrvatske književnosti, no ima ih i bliskih svakodnevnom govoru, a normativne su napomene, iako samo dvije, ipak navedene.

\section{PRISTUPI NARJEČNIM TEMAMA U DRUGIM SREDNJOŠKOLSKIM UDŽBENICIMA}

Pri raščlambi i razradbi narječnih tema zastupljenih u drugim srednjoškolskim udžbenicima kontrastivni se pristup također zapaža u integriranom udžbeniku za treći razred četverogodišnjih strukovnih škola Hrvatski jezik, jezično izražavanje i književnost Marije Znike, Jasne Šego i Jelene Vignjević u udžbeničkoj cjelini Sintaktičke osobitosti hrvatskih narječja. ${ }^{8}$ Na početku te cjeline ponuđeni su istovrsni tekstovi - kraće narodne pjesme, po jedna na svakom narječju. Od sintaktičkih osobitosti izdvojene su i opisane ove: razlika u uporabi neodređenih i određenih pridjevnih oblika, uporaba glagolskih priloga, bezlična uporaba i uporaba supina, uporaba prezenta svršenih glagola umjesto futura za izricanje buduće radnje, uporaba enklitičkog oblika povratno-posvojne zamjenice u dativu si (od sebi), uporaba ličnih umjesto pokaznih zamjenica, izjednačavanje po obliku akuzativa s genitivom kad označuje ne samo živo nego i neživo te mogućnost da se glagolske enklitike mogu nalaziti i na naglašenom mjestu, pa i na početku rečenice. Od čakavskih osobitosti navode se oblici za tvorbu kondicionala koji se rabe umjesto aorista pomoćnog glagola biti, češća uporaba genitiva posvojnog umjesto posvojnog pridjeva i uporaba instrumentala vršitelja radnje umjesto subjekta u nominativu. Od kajkavskih osobitosti izdvojena je uporaba svršenog oblika prezenta glagola biti ili infinitiva umjesto futura I. za izricanje buduće radnje, uporaba nepovratnih glagola kao povratnih i uporaba nominativa umjesto vokativa. I ovdje su dane iste normativne napomene kao u Pranjkovićevu udžbeniku: u svezi s uporabom određenog oblika pridjeva u službi imenskog predikata i povratno-posvojne zamjenice si. Sva navedena jezična obilježja oprimjerena su, kao i u Pranjkovića, rečenicama, samo što su primjeri bliži svakodnevnom govoru, a nema ni upućivanja na stare tekstove.

8 Navedeno vrijedi za prvo (2003) i sva kasnija izdanja tog udžbenika (sedmo izdanje 2009). 
Osim kontrastivnog pristupa pri razradi narječnih tema u srednjoškolskim se udžbenicima zapaža još jedan način njihova predstavljanja. Svako se narječje naime zasebno prikazuje, prvo čakavsko, potom kajkavsko i štokavsko, i to s obzirom na jezične razine koje su kao nastavna tema određene nastavnim programom. U Težak-Diklićevu udžbeniku Hrvatski jezik za prvi razred trogodišnjih strukovnih škola, objavljenom 1998, iste godine kad i Pranjkovićev udžbenik, nakon cjeline Fonemski sustav hrvatskoga standardnoga jezika slijedi cjelina Hrvatska narječja i njihova fonološka obilježja raščlanjena na podcjeline Čakavske glasovne osobine, Kajkavske glasovne osobine i Štokavske glasovne osobine. Ponuđeni su primjeri tekstova svih triju narječja, a birani su ulomci iz starije hrvatske i usmene književnosti, zapisi s terenskih istraživanja dijalektologa i anegdotske sličice iz života. ${ }^{9}$ U gimnazijskim udžbenicima Fon - fon Dragice Dujmović-Markusi, koji se od 2003. i danas objavljuju, ${ }^{10}$ u udžbeniku za prvi razred izložene su fonološke, a u udžbeniku za drugi razred morfološke značajke svih triju narječja s primjerima tekstova starije hrvatske književnosti. U udžbeniku za treći razred udžbenička cjelina Hrvatska narječja raščlanjena je na podcjeline Neke osobitosti čakavskog narječja i Neke osobitosti kajkavskog narječja, a u jednoj i drugoj podcjelini opisuju se i rečenicama oprimjeruju red riječi, uporaba padeža, uporaba određenih i neodređenih oblika pridjeva te uporaba glagola i glagolskih oblika. Također su navedeni primjeri tekstova - kraći ulomci književnih djela druge polovice 20. stoljeća. Od sintaktičkih osobitosti štokavskoga narječja, kojem je posvećena kratka napomena u udžbeniku, spominje se samo uporaba supina. ${ }^{11} \mathrm{Ni}$ u tim udžbenicima ni u Težak-Diklićevu udžbeniku normativnih napomena nema.

Predstavljanje hrvatskih narječja u srednjoškolskim udžbenicima provodi se prema tome na dva načina: kontrastivnim pristupom i zasebnim prikazom jezičnih obilježja pojedinih narječja, koji bi se stoga mogao nazvati deskriptivnim pristupom. Oba su pristupa teorijski utemeljena i oba se primjenjuju u udžbenicima koji su danas u uporabi s tim da je deskriptivni pristup bio uvriježen i u prijašnjim osnovnoškolskim udžbenicima druge polovice 20 . stoljeća. ${ }^{12}$

\footnotetext{
Navedeno vrijedi i za sva kasnija izdanja tog udžbenika (peto izdanje 2003).

Suautorica je istoimenih udžbenika u izdanjima od 2014. Terezija Pavić-Pezer.

Navedeno vrijedi za sva izdanja tog udžbenika.

12 Primjerice v. udžbenik Težaka i Brigljevića Naš jezik za osmi razred osnovne škole $\left({ }^{1} 1962\right.$, 131975. godine).
} 


\section{ZAKLJUČAK}

U gimnazijskom udžbeniku Hrvatski jezik 3 Ive Pranjkovića prvi je put u sintaktičkom opisu hrvatskih narječja primijenjen kontrastivni pristup i time uspostavljen nov model predstavljanja narječnih tema u srednjoškolskim udžbenicima. Budući da je sintaksa i u hrvatskoj dijalektologiji iznimno obrađivana (Bašić i Malnar Jurišić 2016: 66), doprinos je tog udžbenika još značajniji. No bez obzira na to koji se pristup primjenjuje i koja je jezična razina u prvome planu, poželjnim udžbeničkim rješenjima držimo oprimjeravanje ne samo rečenicama nego i tekstovima, onima starije hrvatske i usmene književnosti, a osobito onima iz suvremene komunikacijske prakse, izbjegavanje normativnih napomena i opsegom podjednaku zastupljenost svih triju narječja. S druge strane, promotri li se jezična nastava u okomici odgojno-obrazovnoga sustava, učenici bi u osnovnoj školi trebali spoznati obilježja svog zavičajnog idioma, kojem se pristupa uspoređujući ga sa standardnim jezikom, dakle kontrastivno, dok bi u srednjoj školi trebali spoznati obilježja svih triju narječja hrvatskoga jezika, također uspoređujući ih sa standardnim jezikom, što može pridonijeti boljem svladavanju standardnoga jezika, jezičnim činjenicama potkrijepljenu znanju o hrvatskim narječjima, a u skladu s tim i stjecanju jezične kulture uopće. U tom smislu možda bi ipak kontrastivnom pristupu narječnim temama trebalo dati prednost.

\section{IZVORI}

Dujmović-Markusi, Dragica. 2003. Fon - fon 1. Udžbenik hrvatskoga jezika za prvi razred gimnazije. Zagreb: Profil.

Dujmović-Markusi, Dragica. 2003. Fon - fon 2. Udžbenik hrvatskoga jezika za drugi razred gimnazije. Zagreb: Profil.

Dujmović-Markusi, Dragica. 2004. Fon - fon 3. Udžbenik hrvatskoga jezika za treći razred gimnazije. Zagreb: Profil.

Dujmović-Markusi, Dragica. 2004. Fon - fon 4. Udžbenik hrvatskoga jezika za četvrti razred gimnazije. Zagreb: Profil.

Pranjković, Ivo. 1998. Hrvatski jezik 3. Udžbenik za 3. razred gimnazije. Zagreb: Školska knjiga.

Težak, Stjepko i Zvonimir Diklić. 1998. Hrvatski jezik. Udžbenik za I. razred trogodišnjih strukovnih škola. Zagreb: Znanje.

Znika, Marija, Jasna Šego i Jelena Vignjević. 2003. Hrvatski jezik, jezično izražavanje $i$ književnost. Udžbenik hrvatskoga jezika za četvrti razred četverogodišnjih strukovnih škola. Zagreb: Školska knjiga. 


\section{LITERATURA}

Bampa-Listeš, Silvana. 2003. Razlikovna gramatika mjesnoga govora u Neoriću. "Školski vjesnik", 52, 3-4, 339-359.

Barić, Eugenija i sur. 1995. Hrvatska gramatika. Zagreb: Školska knjiga.

Bašić, Martina i Marija Malnar Jurišić. 2016. Hrvatska dijalektološka istraživanja ščera, danas, jutra. "Croatica", 40, 60, 63-74.

Gudelj-Velaga, Zdenka. 1990. Nastava stvaralačke pismenosti. Zagreb: Školska knjiga.

Lukežić, Iva. 2010. Hrvatski u aktualnome lingvističkom i izvanjezičnom kontekstu. Peti hrvatski slavistički kongres. Plenarna izlaganja [ur. Marija Turk]. Rijeka: Hrvatski slavistički odbor Hrvatskoga filološkog društva; Filozofski fakultet Sveučilišta u Rijeci, 7-19.

Nastavni plan i program za osnovnu školu. 2006. Zagreb: Ministarstvo znanosti, obrazovanja i športa.

Nastavni programi za gimnazije i strukovne škole. 1995. Zagreb: Glasnik Ministarstva prosvjete i športa Republike Hrvatske, posebno izdanje br. 2.

Nemeth-Jajić, Jadranka i Tamara Turza-Bogdan. 2014. Koncepcija narječnih čitanaka. Šesti Hrvatski slavistički kongres. Knjiga sažetaka. Vinkovci - Vukovar-Zagreb: (ur.) Botica, Stipe, Filozofski fakultet Zagreb: 184-184.

Pavličević-Franić, Dunja. 2005. Komunikacijom do gramatike. Zagreb: Alfa.

Peruško, Tone. 1961. Materinski jezik u obaveznoj školi. Zagreb: Pedagoško-književni zbor.

Pranjković, Ivo. 2004. Sintaksa (Hrvatski jezik 3). Priručnik za nastavnike uz udžbenike hrvatskoga jezika za gimnazije [Silić, Josip i sur.]. Zagreb: Školska knjiga, 109-119.

Silić, Josip; Pranjković, Ivo. 2005. Gramatika hrvatskoga jezika za gimnazije i visoka učilišta. Zagreb: Školska knjiga.

Težak, Stjepko. 1980. Gramatika u osnovnoj školi. Zagreb: Školska knjiga.

Težak, Stjepko; Babić, Stjepan. 1992. Gramatika hrvatskoga jezika: priručnik za osnovno jezično obrazovanje. 8. popravljeno izdanje. Zagreb: Školska knjiga. ${ }^{14} 2004$.

Težak, Stjepko. 1996. Teorija i praksa nastave hrvatskoga jezika 1. Zagreb: Školska knjiga.

Turza-Bogdan, Tamara. 2013. Kajkavsko narječje u nastavi Hrvatskoga jezika. Prilozi za osnovnoškolsku nastavu. Čakovec: Matica hrvatska, ogranak Čakovec.

Visinko, Karol. 2010. Jezično izražavanje u nastavi hrvatskoga jezika. Pisanje. Zagreb: Školska knjiga.

Zapisnici Vijeća za normu hrvatskoga standardnog jezika. 2013. “Jezik”, 60, posebno izdanje, 62-149. 


\section{SUMMARY}

\section{THE CONTRASTIVE SYNTAX OF THE CROATIAN LANGUAGE IN THE GRAMMAR SCHOOL TEXTBOOK BY IVO PRANJKOVIĆ: THE CONTRASTIVE APPROACH TO DIALECTAL UNITS}

For the first time within the syntactic description of Croatian dialects in high school textbooks, Ivo Pranjković has applied a contrastive approach, thus introducing a new model of presenting dialectal units. In a chapter of the grammar school textbook Hrvatski jezik 3 (The Croatian Language 3) Pranjković compares the syntactic features of the Chakavian, Kajkavian and Stokavian dialects in their mutual relations as well as in relation to the standard language. The contrastive approach to teaching the Croatian language is not new, but it is still inadequately applied in practice, which is an incentive to analyse the chapter in question with more attention. The paper pinpoints the manifestations of the contrastive approach in this textbook and compares it with the approaches to the dialectical units in other high school textbooks. It also points to the advantages of applying the contrastive approach, as well as to the reasons for its usefulness in the study of the Croatian language at all levels of education.

Key words: Croatian dialects, contrastive approach, Croatian language high school textbooks 